\title{
Improvement of Academic Services using Mobile Technology based on Single Page Application
}

\author{
Hanun Asrohah, Mohammad Khusnu Milad, Achmad Teguh Wibowo, and Erry Ika Rhofita
}

\begin{abstract}
This research discussed the use of SPA-based mobile applications for academic activities at universities. This technology works using asynchronous JavaScript, which can be run by mobile devices and is not limited by the operating system used by mobile phones such as Android, iOS, and others. This way could be reduced the workload of the server because the data sent by a server is not significant compared with a web-based application.
\end{abstract}

Keywords - Academic Services, Mobile application, SPA Technology.

\section{INTRODUCTION}

$\mathrm{N}$ OWADAYS, the role of technology, especially information technology, has become a lifestyle for many people, especially students. The university, as a place of education, is also affected by the advancement of information technology. Today many universities have implemented technology to support their business processes, especially the Islamic State University of Sunan Ampel. The technology was created to facilitate human life in all fields, and mobile technology is one of the fastestgrowing technologies. In 2011 alone, over 300 million apps were developed for mobile phones that run on Android and IOS [1], [2].

Academic service is the core of a university, the teaching process on campus is integral from supporting infrastructure, one of which is information technology [3]. There are many benefits of information technology for academic services, such as finding the course information schedule, final score, GPA Information, and others. For the university to become a superior campus, the role of technology must also be involved in its business processes,

Paper received December 15, 2019; revised April 12, 2020; accepted June 15, 2020. Date of publication July 31, 2020. The associate editor coordinating the review of this manuscript and approving it for publication was Prof. Miroslav Lutovac.

This work was supported by the Research and Community Service Institutions Islamic State University of Sunan Ampel Surabaya under the research grant Number 330 at 2019.

Hanun Asrohah is a lecturer of Faculty of Tarbiyah and Teachers Training UIN Sunan Ampel Surabaya, Indonesia. (email: hanunasrohah@uinsby.ac.id).

Mohammad Khusnu Milad is a lecturer of Faculty Science and Technology UIN Sunan Ampel Surabaya, Indonesia (email: m.milad@uinsby.ac.id).

Achmad Teguh Wibowo is a lecturer of Faculty Science and Technology UIN Sunan Ampel Surabaya, Indonesia (email: atw@uinsby.ac.id)

Erry Ika Rhofita is a lecturer of Faculty Science and Technology UIN Sunan Ampel Surabaya, Indonesia. (email: erryikarhofita@uinsby.ac.id). especially mobile technology.

The use of mobile technology is very appropriate to be implemented for campus academic services. Survey results show that almost all students of the Islamic State University of Sunan Ampel have used smartphones, about $86 \%$ use the Android operating system, $10 \%$ use the IOS operating system and $4 \%$ use other operating systems (Windows Phone, Symbian, etc.)[4]. From this data, mobile-based applications can be implemented at the Islamic State University of Sunan Ampel, especially in the field of academic services.

Much research used mobile technology. The study develops application based-on Android for children to learn essential prayer that could provide a new learning experience with the use of interactive multimedia elements. Thus the application could serve as a tool for teachers and parents [1]. More research has been done with the topic of a mobile visual programming system for Android smartphones and tablets using catroid that allowed users starting from the age of eight to develop their animations and games solely using their Android phones or tablets [5].

Research about experimental case design of "Mobile Divide Programming" for the specialty of information management and information system, discussing learning the content of course "Mobile Device Programming" should be the focus of different content for different specialty, because the course involves many contents but subject to the limitations of the class hour so that this experiment used to improve the students' interested [6].

The research that has been done created a design and mobile application using react-native based on Single Page Application (SPA) technology. This research used a heuristic approach to solve academic services problems so they could be accessed more quickly, not over-load the server and reduce computer usage so energy efficiency (especially electricity) can be achieved. The research also solves the problem of cross-platform mobile programming between Android, iOS, and Windows Phone. Programmers can develop mobile applications more comfortable, without the need to follow an architecture of the mobile device operating system.

This paper is arranged as follows: Section I explains the academic services in the case study, Section II presents the methodology of the research, while Section III briefly presents the relevant work of academic services using React Native and Single Page Application. Section IV shows the requirement analysis of the research. The design and implementation are highlighted in Section V and Section 
VI, respectively. Section VII shows testing and evaluation. Finally, we provide a conclusion of this paper in Section VIII.

\section{Methodology}

The stages of the research are shown in Fig. 1, that is described in the next section.

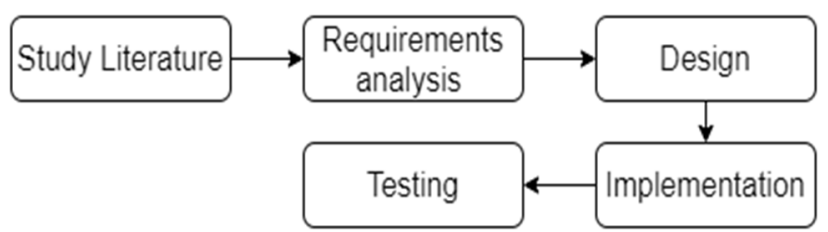

Fig. 1. Methodology of this research.

\section{LITERATURE STUDY}

\section{A. Mobile Operating System}

The mobile operating system is an operating system that controls performance on mobile-based electronic. Similar to Windows, Mac OS X, and Linux function in a desk-top or notebook. Uses of technology are present on smartphones, PDAs, Tablet Computers, etc. Currently, the mobile operating system that is often used is [7]:
1. Android
2. IOS
3. Windows Phone
4. Blackberry OS and
5. Symbian

Currently, the Android operating system is widely used at the Islamic State University of Sunan Ampel, about 86\% of students used the Android operating system. Next, IOS is used by as much as $10 \%$ and the remaining ones by $4 \%$. From the results of this survey, the Islamic State University of Sunan Ampel could give academic services based-on cross-platform mobile programming technology that is not limited to mobile operating system architecture, the technology used is React Native.

\section{B. React Native}

React is a disruptive innovation in web development. Unique architecture SPA and strong third-party support could be applied to a developed native application used JavaScript. React Native is a fast-growing library that used SPA technology. Over the last year, this library has become very popular among the open-source community. There's a new release every other week that improves performance, adds new components, or provides access to new APIs on the device [8], [9].

\section{Single Page Application}

Single Page Application (SPA) is an asynchronous technology JavaScript for front-end and back-end development of an application. This technology makes it possible to users not to switch pages and create a request without reloading a page every time. The user will only load one page from the server, and the routing mechanism usually handled by the server now loads to the client. SPA systems have an excellent UX because they are faster than non-SPA because users always request the server to move pages.

\section{REQUIREMENTS ANALYSIS}

From the results of the literature conducted, it was found that requirement analysis of software and hardware needs to be prepared for developing and running an application that has been created.

Software:

1. Node JS

2. React Native

3. Android Studio

4. Android version 6 or above

5. IOS version 10 or above

Hardware:

1. Computer RAM 8GB or above

2. Smartphone RAM 1 GB or above

3. Hard Disk Computer Space 100GB or above

4. Hard Disk Smartphone Space 16 GB or above

\section{DESIGN}

After conducting a literature study and Requirement analysis, the design of system workflow was obtained in the form of use case diagrams and activity diagrams.

\section{A. Use Case Diagram}

There are two actors in the use-case, namely students and lecturers. Students have access rights to view course schedules, Grade Point Average (GPA), the final score of students in a semester, Personal data while lecturers have access rights to view teaching schedules, GPA guardian students, student's final scores, personal information guardian students, guardian lecturers, supervisor, planning study of students in the next semester, the curriculum is an academic activity provided to students in the form of a course. And all these access rights must go through the login function. The use-case diagram in this research is shown in Fig. 2.

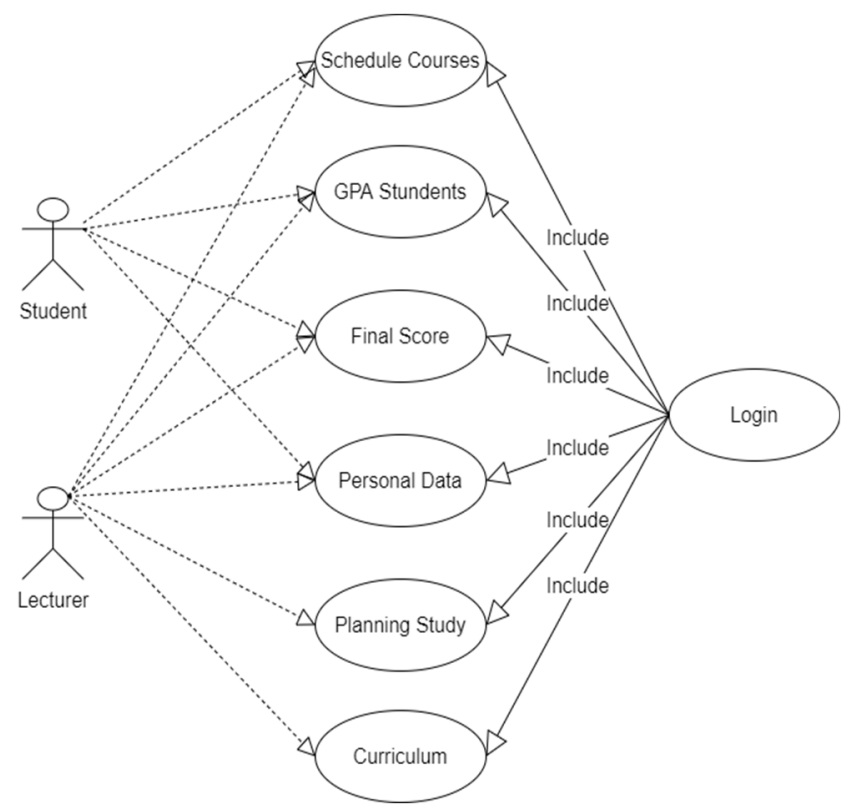

Fig. 2. Use Case Diagram of a Mobile Application for Academic Services. 


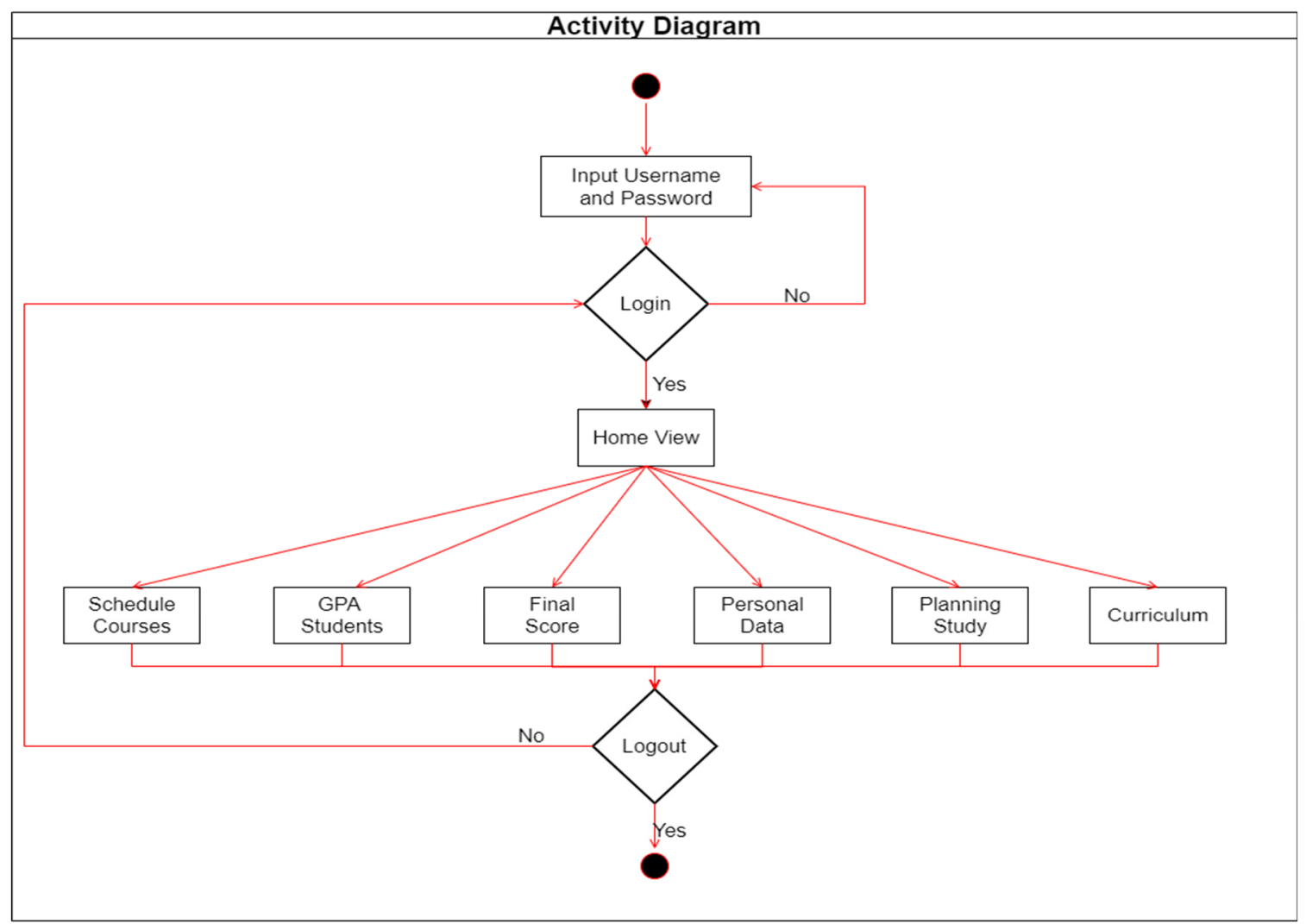

Fig. 3. Activity Diagram of Mobile Application for Academic Services.

\section{B. Activity Diagram}

The first workflow of the user was to input the username and password to perform the login function. If the login function is successful the display of the application would be directed to the home view, users could choose the Schedule Course, GPA Student, Final score students, Personal data, Planning study of students, and Curriculum views. The activity diagram appears in Fig. 3.

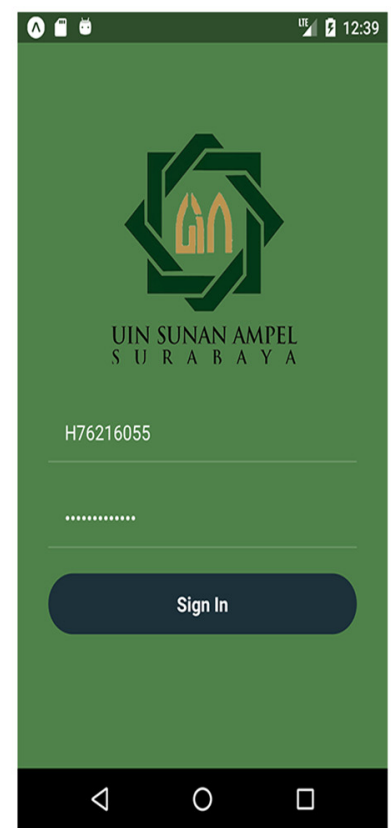

A

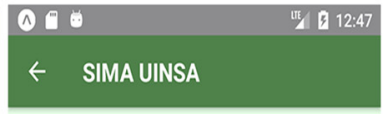

Welcome, BAYU UTOMO Department of Information System
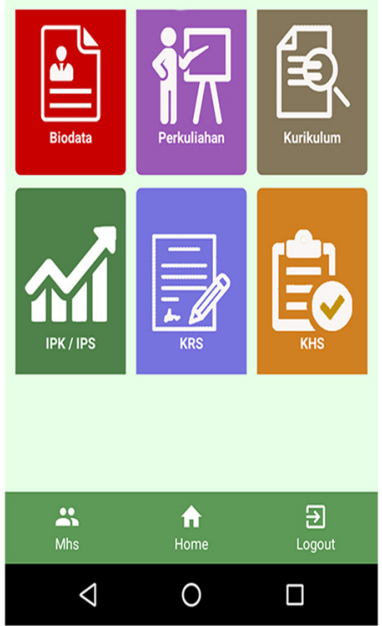

B
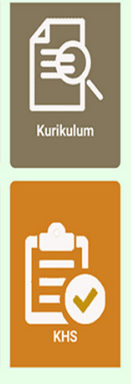

\section{IMPLEMENTATION}

In this section, the implementation of programs was developed using react-native. The results of the UI design implementation that has been developed, are shown in Fig 4.

Fig. 4(A) shows a login form for users consisting of students and lecturers. In this form, there are two inputs,

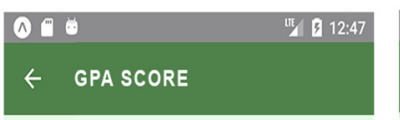

BAYU UTOMO GPA SCORE
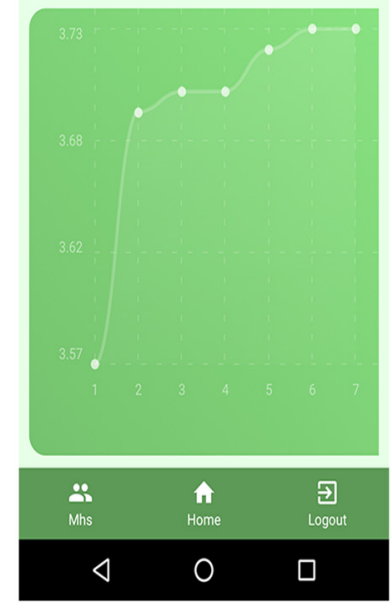

C
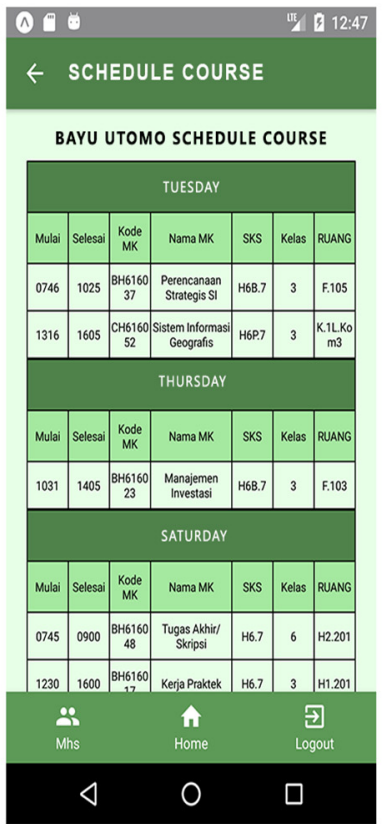

D

Fig. 4. (A)Login Display, (B) Menu Display, (C) Graph of GPA (D) Schedule of Course. 
TABLE 1: BLACKBOX TESTING APPLICATION MENU.

\begin{tabular}{l|l|c}
\hline Menu & Expected Result & Fact Result \\
\hline Login & Displayed 2 Textbox, namely username and password with the Login button & OK \\
Home & $\begin{array}{l}\text { Display a page navigate menu personal data, course schedule, Curriculum, GPA, } \\
\text { Planning Study and Final Score of student }\end{array}$ & OK \\
Logout & Back to Login & OK \\
Personal Data & Display a page personal data from username parameter & OK \\
Home 1 & $\begin{array}{l}\text { Display navigate menu personal data, course schedule, Curriculum, GPA, } \\
\text { Planning Study and Final Score of student }\end{array}$ & OK \\
Course & Displayed a page course schedule from username parameter & OK \\
Schedules & & \\
Home 1 & Display navigate menu personal data, course schedule, Curriculum, GPA, & OK \\
Curriculum & Planning Study and Final Score of student & \\
Home 1 & Display a page curriculum from username parameter & OK \\
Display navigate menu personal data, course schedule, Curriculum, GPA, & OK \\
Home 1 & Planning Study and Final Score of student & OK \\
Final Score & Display a page GPA Student from username parameter & OK \\
Home 1 & Display navigate menu personal data, course schedule, Curriculum, GPA, & \\
Planning Study and Final Score of student & OK \\
Home 1 & Display a page Final Score Student from username parameter \\
& Display navigate menu personal data, course schedule, Curriculum, GPA, & OK \\
\hline
\end{tabular}

that is username and password required to login into the application. Fig. 4(B) shows a dashboard menu of this application. This menu consists of personal data, course schedule, curriculum, GPA, etc. Fig. 4(C) shows a GPA of the student in a graphical form. And Fig. 4(D) shows a course schedule for the student, with the information (days, hours, class, course name, and name of lecturer).

\section{TESTING AND EVALUATION}

Behavioral testing involves a detailed understanding of the application domain, the business problem that the system solves, and the mission the system serves. When testers understand the design of the system, they can augment behavioral tests that effectively find bugs common to that type of design [10]. There are many ways in which the task of black Box testing can be carried out. Some of them are Boundary Value Analysis, Robustness, Worst Case, Equivalence, Cause-Effect and Decision Table Based testing [11].

This test step used three test cases that are when the system runs following expectations, when application runs in Android, IOS and Windows Phone and a numerical measure from human using Mean Opinion Score (MOS). The black box testing results of the application are shown in Table. 1 and the black box testing results on operating system testing Section are shown in Table. 2.

The result of functional testing on a mobile application is shown in table 1 , the first test on the login page showed 2 textboxes with a login button. The first textbox was filled with a true student username and textbox 2 was filled with a student password and reaction when pressing the login button is a move to the home page. The second test on the home page could show display navigates menu personal data, course schedule, curriculum, GPA, Planning Study, and Final Score of student. The third test, when pressing the logout button, is moved to a login page, the fourth test on the personal data page, could show displayed student personal data (student id number, address, mobile phone number, and many more). The fifth test, when pressing the homel button, is a move to the home page.

The sixth test on the course schedule page could show the display student course schedule in 1 week. The seventh test on the Curriculum page could show a display student curriculum that must be taken. The eighth test in the GPA page could show displays of a graph of student GPA values. The result of testing compatibility application run on several mobile operating systems appears in Table 2.

Black box compatibility testing divided at 3 operating systems, the results of testing the Android operating system are as follows:

1. Application is installed on Android version 6 with expectations of success and the results of the application can run well.

2. Application is installed on Android version 7 with expectations of success and the results of the application can run well.

3. Application is installed on Android version 8 with expectations of success and the results of the application can run well.

TABLE 2: BLACKBOX TESTING OF COMPATIBILITY APPLICATION ON SEVERAL MOBILE OS.

\begin{tabular}{l|l|c}
\hline Menu & Expected Result & Fact Result \\
\hline Andorid version 6 & Running & OK \\
Andorid version 7 & Running & OK \\
Andorid version 8 & Running & OK \\
Andorid version 9 & Running & OK \\
IOS version 10 & Running & OK \\
IOS version 11 & Running & OK \\
Windows Phone 8 & Running & Failed \\
\hline
\end{tabular}


TABLE 3: MOS RATING FROM THE RESULT OF AN EVALUATION.

\begin{tabular}{|l|l|r|r|r|r|r|r|r|}
\hline Category & \multicolumn{1}{|c|}{ Factor } & SA & $\boldsymbol{A}$ & $\boldsymbol{D}$ & $\boldsymbol{S D}$ & $\boldsymbol{N O}$ & $\boldsymbol{M O S}$ & \multicolumn{1}{c|}{$\begin{array}{c}\text { MOS each } \\
\text { category }\end{array}$} \\
\hline Usability & The application easy to use & 40 & 10 & & & & 4,8 & \\
& The application is running well & 38 & 12 & & & & 4,7 & \\
& The application easy to understand & 42 & 8 & & & & 4,8 & \\
& The UI of an application is attractive & 40 & 5 & 5 & & & 4,7 & \\
\hline Functional & The UI for input is easy to enter & 42 & 8 & & & & 4,8 & 4,8 \\
\hline Performance & The application provides a fast response & 38 & 12 & & & & 4,7 & \\
& The application successfully load data from 3G & 46 & 4 & & & & 4,9 & \\
& and 4G network & & & & & & \\
\hline Overall & The application can help academic services & 41 & 9 & & & & 4,8 & \\
\hline
\end{tabular}

4. Application is installed on Android version 9 with expectations of success and the results of the application can run well.

The result of testing the IOS operating system is as follows:

1. Application is installed on IOS version 10 with expectations of success and the results of the application can run well.

2. Application is installed on IOS version 11 with expectations of success and the results of the application can run well.

The result of testing the Windows Phone operating system is as follows:

1. Application is installed on Windows Phone 8 with expectations of success and the results of the application can't run well.

Furthermore, the evaluation of the system MOS was performed. This evaluation was based on the numerical from humans to measure the overall quality of an event or experience. MOS is a means from a predetermined value to representatives of the subject's opinion about the quality of the system. Generally, the MOS scale ranges from 1 to 5, where one is the worst and five is the best. The MOS equation is a follows:

$$
M O S=\frac{\sum_{n=0}^{N} R_{n}}{N}
$$

In this research, evaluate the system using MOS by giving questionnaires to the user. There are five scores with a certain weight, namely strongly agree $(\mathrm{SA})=5$, agree $(\mathrm{A})$ $=4$, disagree $(\mathrm{D})=3$, strongly disagree $(\mathrm{SD})=2$, and no opinion $(\mathrm{NO})=1$. The result of the MOS was obtained from 50 system users. Table 3 shows the MOS rating.

The MOS result of each category was calculated using equation (1) and the calculation for overall score is a follows:

$$
\text { SystemScore }=\frac{(4.7+4.8+4.8+4.8)}{4}=4.7
$$

The evaluation system based on MOS gave 4.7 of the total value of 5 and concluded that the application is useful and could be accepted by users.

\section{CONCLUSION}

This research was implemented with SPA technology using react-native as front-end programming and Node.JS as backend-programming for academic services at the Islamic State University of Sunan Ampel. This solution could improve academic services while reduced electrical efficiency in a computer of used and server workloads could be achieved.

Developed applications based on React Native had many advantages compared to the use of native mobile programming. React Native makes it easier for programmers to create mobile apps without limit for the operating system architecture of mobile devices. The results of the tests carried out in table 1 show that all menus run as expected. While testing in table 2, the application developed could run into the Android and IOS operating system, but there is an implementation failure in the Windows Phone operating system. This problem should be focused in future research.

\section{REFERENCES}

[1] N. Hamzah, N. D. Abd Halim, M. H. Hassan, and A. Ariffin, "Android Application for Children to Learn Basic Solat," Int. J. Interact. Mob. Technol., vol. 13, no. 07, p. 69, 2019.

[2] M. Nizam, "Aplikasi Mudah Alih Pengimbas Kod E Menggunakan Teknologi Pengecaman Aksara," FTSM, 2016.

[3] K. Anam, "Analisa Dan Perancangan Sistem Informasi Akademik Berbasis Web Pada Mi Al-Mursyidiyyah Al-'Asyirotussyafi'Jyyah,' J. Tek. Inform., vol. 11, no. 2, pp. 207-217, 2018.

[4] F. Uinsa, "Survey Penggunaan Smartphone," Surabaya, 2018

[5] W. Slany, "Catroid: A mobile visual programming system for children," ACM Int. Conf. Proceeding Ser., no. April 2012, pp. 300 303, 2012.

[6] X. Yang and J. Yang, "Course Reform of Mobile Device Programming for Information Management and Information System," no. Icemaess 2015, pp. 1260-1264, 2016.

[7] TIM Dosen Mercubuana, Rekayasa Perangkat Lunak Pusat Bahan Ajar dan eLearning Rekayasa Perangkat Lunak. Jakarta: Universitas Mercu Buana, 2016.

[8] S. Bershadskiy and C. Villa, React Native Cookbook Take your React Native application development to the next level with this large collection of recipes, 1st ed. Birmingham: Packt, 2016.

[9] D. Ferdiand, "Mengenal Single page application(SPA)," 2017. [Online]. Available: https://degananda.com/mengenal-single-pageapplication-spa/. [Accessed: 10-Jul-2019].

[10] R. Black, Managing the Testing Process: Practical Tools and Techniques for Managing Hardware and Software Testing. Indianapolish: Wiley Publishing, 2009.

[11] H. Bhasin, E. Khanna, and S. Sudha, "Black Box Testing based on Requirement Analysis and Design Specifications," Int. J. Comput. Appl., vol. 87, no. 18, pp. 36-40, 2014. 